Int. J. Dev. Biol. 51: 157-160 (2007)

doi: $10.1387 /$ ijdb.062203al

Technical Article

\title{
Isolation of apoptotic mouse fetal oocytes by AnnexinV assay
}

\author{
ANNA-MARIA LOBASCIO\#, FRANCESCA-GIOIA KLINGER ${ }^{\#}$ and MASSIMO DE FELICI* \\ Department of Public Health and Cell Biology, Section of Histology and Embryology, University of Rome "Tor Vergata", Rome, Italy.
}

\begin{abstract}
Expression of phosphotidylserine by fetal oocytes in culture renders significant numbers of such cells able to bind AnnexinV-coated microbeads and allows their separation from Annexin V-negative oocytes on a Magnetic Cell Separation (MACS) column in a magnetic field. The majority of oocytes ( $\geq 75 \%)$ which bound Annexin V-coated microbeads were viable, as indicated by their propidium iodine (PI) negativity. However, they showed apoptotic morphologies and were found to be TUNEL-positive. On the other hand, AnnexinV-negative oocytes, besides being PI negative, appeared morphologically healthy and TUNEL negative. Moreover, AnnexinVpositive oocytes showed a marked lower ratio of $\mathrm{Bcl}-\mathrm{xL} / \mathrm{Bax}$ transcripts in comparison to AnnexinV-negative oocytes. We conclude that the present method is able to separate fetal oocytes in two distinct populations: AnnexinV-positive oocytes showing features typical of apoptotic cells and AnnexinV-negative oocytes comprising for the most part viable non-apoptotic cells. This procedure should greatly facilitate studies aimed to identify the currently poorly understood molecular pathways governing apoptosis in mammalian fetal oocytes.
\end{abstract}

KEY WORDS: apoptosis, oocytes, annexinV, meiosis

\section{Introduction}

In mammals, extensive degeneration of female germ cells has been described during embryonic and fetal stages of oogenesis. According to several reports fetal oocyte death takes place as programmed cell death (PCD) in the form of apoptosis. However, the cause/s and the molecular mechanisms underlying oocyte PCD are little understood (for reviews, see Morita and Tilly, 1999; Tilly, 2001; Morita et al., 2001; De Felici et al., 2005). In general a major problem in studying the molecular mechanisms of cell apoptosis is to obtain sufficient quantities of homogeneous experimental material for biochemical analyses. In vivothe number of apoptotic cells present at any time inside tissues is low. In fact, in the mouse fetal ovaries only a few oocytes showing apoptotic markers such as TUNEL and/or Poly (ADP-Ribose) Polymerase (PARP) staining are identifiable (Pesce etal., 1997; Reynaud and Driancurt, 1999; Pepling and Spradling, 2001; Kasai et al., 2003). In previous works, we showed that isolated mouse fetal oocytes cultured in vitro in conditions allowing their meiotic progression, underwent cell death resembling apoptotic waves occurring in oocytes within the fetal ovaries (De Felici et al., 1999; Lobascio et al., 2006). In particular, we found that the number of oocytes showing TUNEL staining and AnnexinV binding increased as a function of the culture time and meiotic progression (Lobascio et al., 2006 submitted). While positive TUNEL staining reveal DNA cleavage associated to relatively late stages of apoptosis (Gavrieli et al., 1992), AnnexinV binding is known to result from the loss of phospholipid asymmetry and phosphotidylserine (PS) exposure on the outside surface of the plasma membrane occurring in the early stages of apoptosis (Martin et al., 1995). Taking advantage of this latter process, we sought to devise a method to separate AnnexinV positive and negative oocytes in culture and to verify if distinct apoptotic and non apoptotic oocyte populations could be obtained.

\section{Experimental Protocols}

\section{Oocyte isolation and culture}

Oocytes were isolated in $\mathrm{M}_{2}$ medium (Sigma, Milan, Italy) from 10-20 ovaries of $15.5 \mathrm{dpc}$ CD-1 mouse embryos by EDTA-stab method as described in De Felici and McLaren (1982). Briefly, after collection, ovaries were transferred to $0.01 \%$ EDTA solution in PBS for 15-20 min at room temperature. The ovaries were then washed in $\mathrm{M}_{2}$ and cells released by pricking the ovaries with fine needles. This method allows to isolate monodispersed cell population containing about $70-80 \%$ oocytes. Oocytes (about $2-4 \times 10^{4}$ / $\mathrm{ml}$ ) were then cultured in $5 \mathrm{ml}$ Falcon tube for three days at $37^{\circ} \mathrm{C}$ in $5 \% \mathrm{CO} 2$ in $0.5 \mathrm{ml}$ of MEM supplemented with $5 \%$ horse serum (HS, Invitrogen, Milan, Italy) and $2.5 \%$ heat-inactivated fetal calf

Abbreviations used in this paper: dpc, days post coitum; GCNA, germ cell nuclear antigen; MACS, magnetic cell separation; PI, propidium iodide.

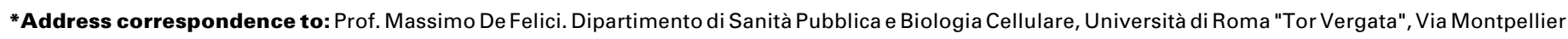
1, 00173 Roma, Italy. Fax: 39-06-7259-6172. e-mail: defelici@uniroma2.it
}

\# Note Both authors contributed equally to this paper. 

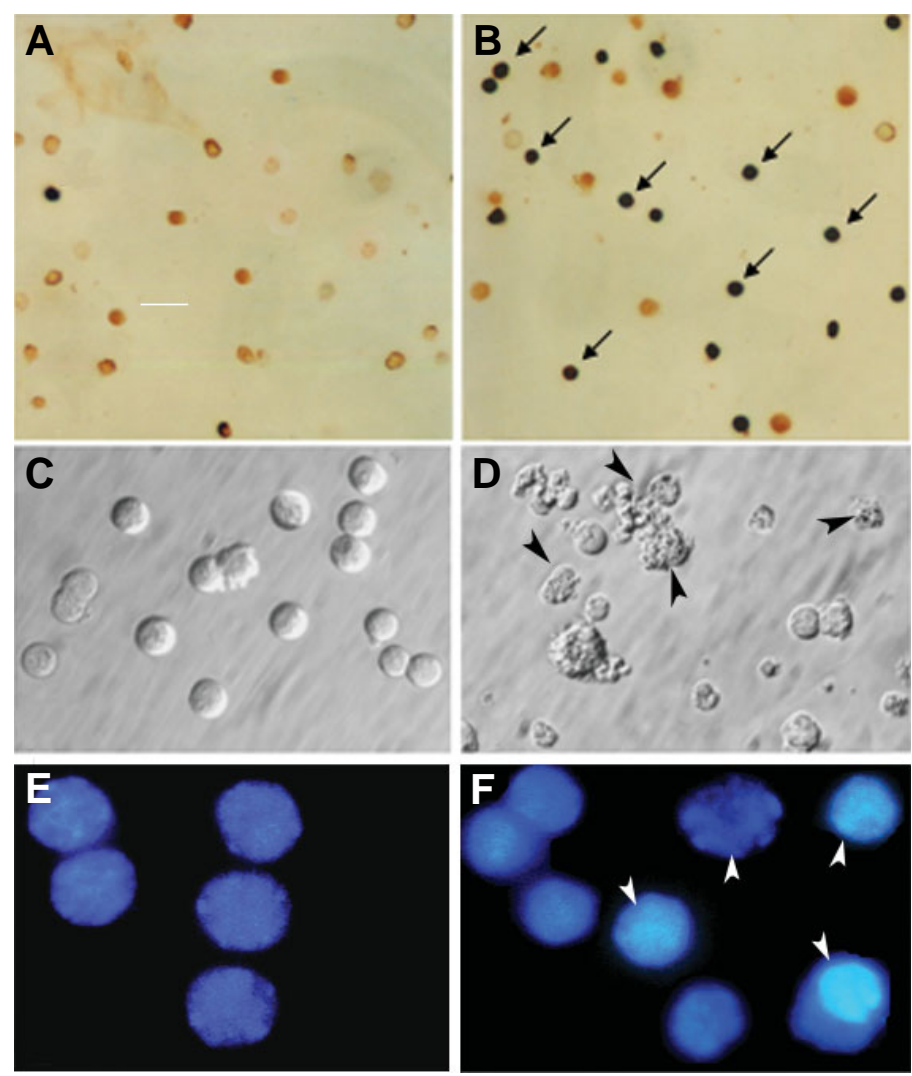

Fig. 1. Analysis of $\mathbf{1 5 . 5}$ dpc oocytes cultured for $\mathbf{3}$ days and sorted with AnnexinV-coated microbeads. While the most part of Annexin Vnegative sorted oocytes were negative to TUNEL staining (A), the most part of the AnnexinV-positive sorted oocytes resulted TUNEL positive (B) (see arrows). Higher magnifications under light microscope of AnnexinVnegative (C) and-positive (D) sorted oocytes. Note the high frequency of poor morphologies (arrowheads) in this latter oocyte population. (E,F) Nuclear staining with Hoechst 33248 of Annexin V-negative and positive oocytes respectively. Note chromatin condensation typical of apoptotic cells (arrowheads) in (F).

serum (FCS, Invitrogen) as described in De Felici et al. (1999).

\section{Annexin $V$ binding and cell sorting}

At the beginning (T0) and after 3 days of culture (T3) samples of oocytes were examined for AnnexinV binding and propidium iodure (PI) staining using the Annexin V-FITC detection kit (Calbiochem, VWR International s.r.l., Milan, Italy) following the protocol of the manufacture.

AnnexinV cell sorting was carried out using the AnnexinV Microbead kit from Miltenyi Biotechnology (Bologna, Italy). Briefly, samples of oocytes were washed in AnnexinV binding buffer by centrifugation ( $800 \mathrm{~g} \times 15 \mathrm{~min}$ at room temperature), resuspended in $100 \mu \mathrm{l}$ of AnnexinV-coated microbeads and incubated for 15 min at room temperature in continuous agitation. At the end of incubation $0.9 \mathrm{ml}$ of $\mathrm{M}_{2}$ medium containing $5 \% \mathrm{BSA}$ (Sigma) was added to the cells and the sample passed through a $\mathrm{MS}^{+}$column in a magnetic field (Miltenyi Biotechnology). Flushed AnnexinVnegative cells were collected in $1 \mathrm{ml}$ of medium in a $1-\mathrm{ml}$ Eppendorf tube. The column was then washed two times with $1 \mathrm{ml}$ of $M_{2}$ in the magnetic field. To elute AnnexinV-positive cells retained by the column, this was removed from the magnetic field, placed on a 1-ml Eppendorf tube and flushed out with $1 \mathrm{ml}$ of $\mathrm{M}_{2}$ using the plunger supplied with the column. Samples of effluent and retained cells were then processed for Germ Cell Nuclear Antigen 1 (GCNA-1) staining and TUNEL assay or subjected to RT-PCR analysis.

\section{GCNA-1 staining, TUNEL assay and Hoechst labeling}

GCNA-1 immunolabelling specific for oocytes (Enders and May, 1994) and TUNEL assay for apoptosis evaluation were performed on separate cell samples of the same cell populations as described in detail in Lobascio et al. (2006, Submitted).

Briefly, for GCNA-1 labelling, $20 \mu$ of the cell suspension were spotted onto L-polylysine-coated slides and fixed with $4 \%$ paraformaldehyde for $10 \mathrm{~min}$, washed three times each for $10 \mathrm{~min}$ in PBS containing $0.5 \%$ BSA. A 15 min block in PBS containing 0.3\% BSA, $0.05 \%$ X-Triton, $1 \%$ goat serum was performed. The slides were then incubated over night treated with 1:2 anti GCNA-1 antibody kindly provided by Dr. G. Enders (University of Kansas, Kansas, KS; Enders and May, 1994). The next day the slides were washed in PBS plus $0.5 \% \mathrm{BSA}$ and incubated for $45 \mathrm{~min}$ with a goat anti-rat IgM fluorescein isothiocyanate (FITC) conjugated antibody (AlexaFluor, Invitrogen).

For TUNEL staining, $50 \mu$ l of the cell suspension were mixed with an equal volume of $1.5 \%$ low melting point $\left(37^{\circ} \mathrm{C}\right)$ agarose in PBS. Aliquots $(50 \mu \mathrm{l})$ were smeared onto glass slides and allowed to solidify at room temperature. TUNEL-positive cells were identified according to the protocol of the in situ cell death detection kit, POD (Roche Diagnostics, Monza, Italy).

GCNA-1 and TUNEL-positive cells were scored in several fields for a total of at least 300 cells under a $40 \mathrm{X}$ objective of a Zeiss Axioplan 2 microscope.

Nuclei of cells fixed with $4 \%$ paraformaldehyde for 10 min were stained with $1 \mu \mathrm{g} / \mathrm{ml}$ Hoechst 33248 (Sigma), for 5-10 minutes at room temperature.

\section{RT-PCR}

Reverse transcriptase-polymerase chain reaction (RT-PCR) was used in order to analyse the level of Bax and Bcl-xL transcripts. Briefly, approximately 100 cells were used for each reaction and mRNA was obtained adding $1.5 \mu \mathrm{l}$ lysis buffer $(0.1 \mathrm{M}$ DTT, $0.48 \mu \mathrm{l}$ Igepal, 0.6U RNase OUT). mRNA was reversedtranscribed with Super Script First Strand Synthesis System for RT-PCR (Invitrogen) according to manufacture instruction. The resulting cDNA fragments were amplified using Taq DNA polymerase (Invitrogen). Primer sequences for $\mathrm{Bcl}-x<$ were forward primer: 5'-GACCGCGTATCAGAGCTTTG-3' and reverse primer: 5'-TCACTTCCGACTGAAGAGTG-3', for Bax were forward primer: 5'-ATGCGTCCACCAAGAAGCTGAG-3' and reverse primer: 5'CCCCAGTTGAAGTTGCCATCAG-3' and for $\beta$-actin as an internal control were forward primer: 5'AGCCACGATTTCCCTCTCAGC-3' and reverse primer: 5'GGCCCAGAGCAAGAGAGGTATCC-3' (Nichols et al., 1998).

\section{Results and Discussion}

Co-staining with PI to determine the integrity of the plasma membrane and FITC-AnnexinV to determine the transition of PS was used to distinguish necrotic, apoptotic and viable not apop- 

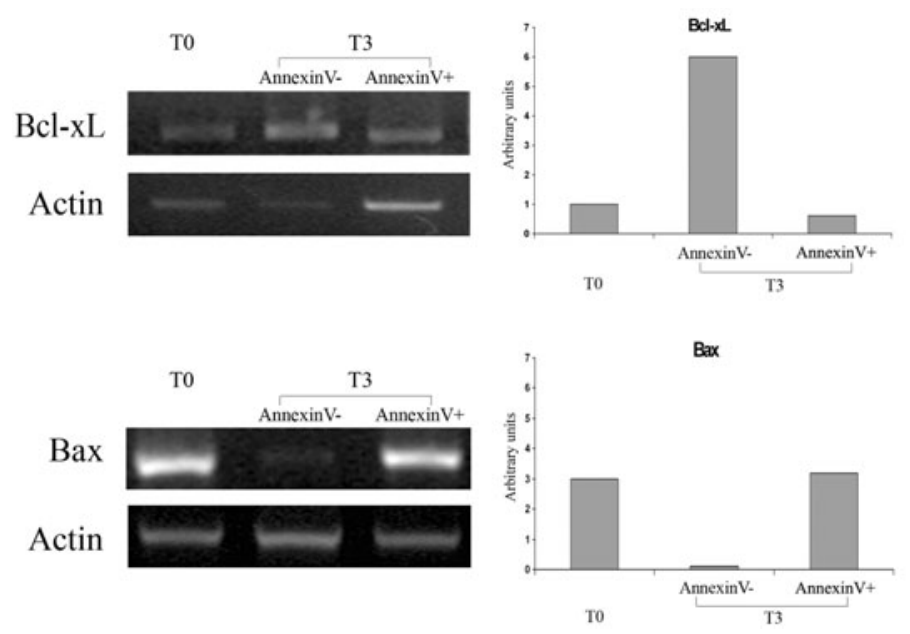

Fig. 2. RT-PCR analyses for Bax and $B c l-x L$ transcripts in AnnexinVnegative and -positive sorted cells. After 3 days of culture (T3), sorted Annexin $V+$ oocytes showed a marked lower Bcl-xL/Bax transcript ratio than Annexin $V$ - oocytes.

totic cells. The number of cells morphologically identified as oocytes showing AnnexinV binding increased from 2-5\% at T0 to $40 \% \pm 5.5$ (mean \pm SE) at T3. A few PI stained oocytes were present at T0 $(<10 \%)$; at T3 these cells increased to $15-25 \%$ and about half of them were AnnexinV positive.

Separation of AnnexinV positive and negative oocytes was carried out at T3 following the procedure described in Materials and Methods. The results of three independent experiments are reported in Table 1. It appears that this procedure resulted effective in separating cells in two distinct populations of AnnexinV positive (about $52 \% \pm 5.8$, mean \pm SE) and negative (about $48 \% \pm 5.8$ ) cells. The former showed apoptotic morphologies (reduced size, cell fragmentation and condensed chromatin) and were $72 \pm 7.2 \%$ and $82 \pm 3.5 \%$ GCNA- 1 and TUNEL positive, respectively, while the latter showed healthy morphologies and were $65 \pm 8.4 \%$ GCNA-1 positive and $92 \pm 3.8 \%$ TUNEL negative (Fig. 1).

Moreover, RT-PCR analyses of mRNA of the anti apoptotic $b c /-x L$ and the pro apoptotic bax genes showed that at T3 AnnexinV-positive cells had a marked lower $\mathrm{Bcl}-\mathrm{xL} / \mathrm{Bax}$ ratio transcripts than Annexin V-negative Cells (Fig. 2). Such difference appears mainly due to a marked increase of the levels of Bcl$\mathrm{xL}$ transcripts in the AnnexinV-negative oocytes rather than to changes of transcripts of the two genes in AnnexinV-positive oocytes in comparison to T0. Thus suggesting that the low $\mathrm{Bcl}-\mathrm{xL} /$

\section{TABLE 1}

\section{ANNEXIN V SORTING OF 15.5 DPC OOCYTES CULTURED FOR THREE DAYS}

\begin{tabular}{lcc} 
& AnnexinV+ (\%) & AnnexinV- (\%) \\
\hline Exp.1 & 60 & 40 \\
Exp.2 & 42 & 58 \\
Exp.3 & 56 & 42 \\
\hline
\end{tabular}

In each experiment, roughly $2-6 \times 10^{3}$ oocytes were recovered in the sorted cell populations.
Bax ratio found also in freshly isolated $15.5 \mathrm{dpc}$ oocytes at T0 is not sufficient at this time for apoptosis and that, at least in our culture condition, high $\mathrm{Bcl}-\mathrm{xL}$ expression is necessary for the maintenance of oocyte survival. We conclude that the present method is able to separate fetal oocytes in two distinct populations. Annexin V-positive oocytes showing several features typical of apoptotic cells and Annexin V-negative oocytes comprising for the most part viable not apoptotic cells. According to several reports fetal oocyte degeneration takes place in the form of apoptosis (Pesce et al., 1993; Coucouvanis et al., 1993; Pesce and De Felici, 1994; Del Pol et al., 1997; Abir et al., 2002; Modi et al., 2003). The process of oocyte apoptosis remains, however, incompletely characterized and alternative forms of cell death for fetal germ cells remain possible (Wartemberg et al., 2001). Furthermore the causes and the molecular mechanisms underlying oocyte apoptosis are little understood (for reviews, see Morita and Tilly, 1999; Tilly, 2001; De Felici et al., 2005). An impediment in the investigation of the molecular mechanisms of the fetal oocyte apoptosis has been the lack of an appropriate system for experimental analyses. The procedure of oocyte separation described here can be useful to further characterize cell death occurring in fetal oocytes and to investigate the molecular pathways underlying this crucial process of the early oogenesis.

\section{Acknowledgments}

This work was supported by EU QLRT-2001-02403) and ASI grant (2006).

\section{References}

ABIR, R., ORVIETO, R., DICKER, D., ZUKERMAN, Z., BARNETT, M., FISCH, B. (2002) Preliminary studies on apoptosis in human fetal ovaries. Fertility and sterility 78: 259-264

COUCOUVANIS, E.C., SHERWOOD, S.W., CARSWELL-CRUMPTONM, C., SPACK, E., JONES, P.P. (1993) Evidence that the mechanism of prenatal germ cell death in the mouse is apoptosis. Exp. Cell. Res. 209: 238-246

DE FELICI, M., MCLAREN, A. (1982) Isolation of mouse primordial germ cells Exp. Cell. Res. 142: 476-282

DE FELICI, M., DI CARLO, A., PESCE, M., IONA, S., FARRACE, M.G., PIACENTINI, M. (1999). Bcl-2 and Bax regulation of apoptosis in germ cells during prenatal oogenesis in the mouse embryo. Cell Death Diff. 6: 908-915.

DE FELICI, M., KLINGER, F.G., FARINI, D., SCALDAFERRI, M.L., IONA, S., LOBASCIO, M. (2005) Establishment of oocyte population in the fetal ovary: primordial germ cell proliferation and oocyte programmed cell death. Reprod Biomed Online 10: 182-91.

DEL POL, A., VACCINA, F., FORABOsco, A., CAVAZZUTI, E. MARZONA, L. (1997) Apoptosis of germ cells during human prenatal oogenesis. Hum. Repr. 10: 2235-2241

ENDERS, G.C., MAY, J.J. (1994) Developmentally regulated expression of a mouse germ cell nuclear antigen examined from embryonic day 11 to adult in male and female mice. Dev Biol. 163: 331-40.

GAVRIELI, Y., SHERMAN, Y., SHMUEL, A. BEN-SASSON, A. (1992) Identification of programmed cell death in situ via specific labelling of nuclear DNA fragmentation J. Cell. Biol. 119: 493-501.

KASAI, S., CHUMA, S., MOTOYAMA, N., NAKATSUJI, N. (2003) Haploinsufficiency of $\mathrm{Bcl}-\mathrm{x}$ leads to male-specific defects in fetal germ cells: differential regulation of germ cell apoptosis between the sexes. Dev Biol. 264: 202-16.

LOBASCIO, A.M., KLINGER,F.G., SCALDAFERRI, M.L., FARINI, D., DE FELICI, M. (2006) Analysis of programmed cell death in mouse fetal oocytes. Submitted

MARTIN, S.J., REUTELINGSPERGER, C.P., MCGAHON, A.J., RADER, J.A., VAN SCHIE, R.C., LAFACE, D.M., GREEN, D.R. (1995) Early redistribution of plasma membrane phosphatidylserine is a general feature of apoptosis regard- 
less of the initiating stimulus: inhibition by overexpression of $\mathrm{Bcl}-2$ and $\mathrm{Abl}$. JExp Med. 182: 1545-56

MODI, D.N., SANE, S. BHARTIYA, D. (2003) Accelerated germ cell apoptosis in sex chromosome aneuploid fetal human gonads. Mol.Hum.Rep. 9: 219-225

MORITA, Y., TILLY, J.L. (1999) Oocytes apoptosis: like sand through an hourglass Dev. Biol.

213: 1-17.

MORITA, Y., TSUTSUMI, O. TAKETANI, Y. (2001) Regulatory mechanisms of female germ cell apoptosis durino embryonic development. Endocrine Journal 48: $289-301$.

NICHOLS, J., ZEVNIK, B., ANASTASSIADIS, K., NIWA, H., KLEWE-NEBENIUS, D., CHAMBERS, I., SCHOLER, H., SMITH, A. (1998) Formation of pluripotent stem cells in the mammalian embryo depends on the POU transcription factor Oct4. Cel/95: 379-91.

PEPLING, M.E., SPRADLING, A.C. (2001) Mouse ovarian germ cell cysts undergo programmed breakdown to form primordial follicles. Dev. Biol. 234: 339-351.

PESCE, M., FARRACE, M.G., DOLCI, S., PIACENTINI, M., DE FELICI, M. (1993) Stem cell factor and leukemia inhibitory factor promote primordial germ cell survival by suppressing programmed cell death (apoptosis). Development118: 1089-1094
PESCE, M., DE FELICI, M. (1994) Apoptosis in mouse primordial germ cells: a study by transmission and scanning electron microscope. Anat. Embryol. 189: 435-440

PESCE, M., FARRACE, M.G., AMENDOLA, A., PIACENTINI, M., DE FELICI, M. (1997) Stem cell Factor Regulation of apoptosis in mouse primordial germ cells. Cell Death in Reprod Physiol. Ed. Springer-Verlag N.Y. 19-31.

REYNAUD, K., DRIANCOURT, M.A. (2000) Oocyte attrition. Mol Cel/ Endocrinol. 163: 101-8.

TILLY, J.L. (2001) Commuting the death sentence: how oocytes strive to survive Nature Rev Mol Cell Biol2: 838-848.

WARTENBERG, H., IHMER, A., SCHWARZ, S., MIETHING, A., VIEBAHN, C. (2001) Measurement of apoptosis in long-term cultures of human ovarian tissue. Reproduction 122: 657-63.

Received: 1st August 2006 Reviewed by Referees: 18th October 2006 Modified by Authors and Accepted for Publication: 1st December 2006 Published Online: 31st January 2007 